\title{
Artificial Intelligence (AI) and Sustainable Development Goals (SDGs): Exploring the Impact of AI on Politics and Society
}

\author{
Anna Visvizi ${ }^{1,2}$ (D)
}

Citation: Visvizi, A. Artificial Intelligence (AI) and Sustainable Development Goals (SDGs):

Exploring the Impact of AI on Politics and Society. Sustainability 2022, 14, 1730. https://doi.org/10.3390/ su14031730

Received: 26 January 2022

Accepted: 1 February 2022

Published: 2 February 2022

Publisher's Note: MDPI stays neutral with regard to jurisdictional claims in published maps and institutional affiliations.

Copyright: (C) 2022 by the author. Licensee MDPI, Basel, Switzerland. This article is an open access article distributed under the terms and conditions of the Creative Commons Attribution (CC BY) license (https:// creativecommons.org/licenses/by/ $4.0 /)$.
1 Institute of International Studies (ISM), SGH Warsaw School of Economics, Al. Niepodległości 162, 02-554 Warsaw, Poland; avisvi@sgh.waw.pl

2 Effat College of Business, Effat University, Jeddah 21551, Saudi Arabia

In popular discourse, artificial intelligence (AI) has turned into one of the most inexplicable issues It has turned into an artifact that people do not dare to question. As a result, in as much as references to $\mathrm{AI}$ are frequent, they also tend to be devoid of substance. In contrast, the academic debate on $\mathrm{AI}$ is filled with ever more interesting accounts of what $\mathrm{AI}$ is [1,2], how to conceptualize it [3], what dilemmas it triggers [4,5], and-perhaps most importantly-how AI can benefit our societies [6-8]. A cognitive divide has emerged between the general audience, the decision makers and the community of experts dealing with AI and related topics. This divide ought to be bridged. Only in this way will the stakeholders be able to engage in the still nascent debate on AI and its role in modern societies. However, the challenge is bigger than that. That is, the thrust, the value, and the promise of AI and AI-based systems, solutions, and applications still need to be effectively communicated to decision makers. Only in this way will they be able to deal with the topic and its ramifications in the manner that is required. An effective, i.e., clear, direct, and simple (but not simplistic) way of emulating knowledge and understanding of AI to all society members which is devoid of superfluous jargon (and yet is serious) is an imperative that the academic community has to embrace. This Special Issue sought to encourage it.

By framing the conversation with the United Nations' Sustainable Development Goals (SDGs), the objective of this Special Issue was to nurture a conversation on diverse aspects of AI and several fields of application, including AI and its role in promoting inclusive and sustainable growth and development. Several manuscripts were submitted in response to the initial call for papers. However, only seven papers were eventually accepted and included in this Special Issue. The following section offers an overview of these papers.

The Special Issue opens with a discussion on AI in and the SDGs, whereby the central tenet of the argument is defined by the notion of the unsustainability of the sociotechnical system [9]. As the author argues, AI has great positive potential; however, it is also intimately linked to nonuniversal access to increasingly large data sets and the computing infrastructure required to make use of them. In this view, a great number of questions are raised as to how to harness the value and potential of AI for our societies. In what follows, Reis et al. [10] explore the impact of AI on politics in the European Union (EU). With a direct focus on Portugal, the findings suggest that solutions, such as intelligent decision support systems, tend to improve the political decision-making process, and therefore, have positive impacts on Portuguese society at local, regional, and national levels. At the same time, as noted by Saetra [9], a great number of challenges emerge when AI and AI-based solutions are applied in contexts that require the handling and protection of patient/citizen data and critical information.

Nevertheless, as the authors of the next paper [11] argue, AI and, more specifically, machine learning (ML) may revolutionize the process of data collection and analysis, especially when applied in the context of poverty identification and classification. This in turn may allow more timely and more accurate policy responses. Poverty is a frequent cause of social exclusion. If contested cultural identity is added to the equation, the policymaking 
challenge becomes exponential. Cultural identity, as the following paper highlights [12], is a complex concept that includes subjective factors such as ideology, family knowledge, customs, language, and acquired skills, among others. The prospect of measuring it bears the promise of more accurate ways of dealing with the challenges that it brings about. This task was undertaken by Espin-Leon et al. [12] who developed a method of computing cultural identity distance and applied it to the case of the Waorani community.

The business sector is a vast field, where AI and AI-based solutions are tested and applied on a daily basis [13]. The COVID-19 pandemic created a new environment where business' capacity to use AI could be tested. Accordingly, Chen et al. [14] outline five major related business challenges: production and supply-chain disruption, appropriate business model selection, inventory management, budget planning, and workforce management. Consequently, the authors elaborate how $\mathrm{AI}$ and big data may be consequential in effectively addressing these challenges. The following paper [15] explores another aspect of the broader AI ecosystem, i.e., blockchain and its potential to ease conventional and replicable practices, for instance, in the field of administration. While this paper focuses specifically on the challenge of verifying the integrity of academic certificates, the findings can easily be applied in a number of different contexts. The Special Issue closes with a contribution by Meppelink et al. [16], who propose a method of using mobile phone data to obtain reliable information on traffic, etc. To sum up, the discussion on AI and its value for our societies has only just begun. As advancements in AI and its ecosystem [1] proliferate, it is imperative that corresponding insights into these technological developments are provided by the remaining communities of scholars and practitioners.

Funding: This research received no external funding.

Institutional Review Board Statement: Not applicable.

Informed Consent Statement: Not applicable.

Data Availability Statement: Not applicable.

Conflicts of Interest: The author declares no conflict of interest.

\section{References}

1. Visvizi, A.; Bodziany, M. (Eds.) Artificial Intelligence and Its Contexts. Advanced Sciences and Technologies for Security Applications; Springer: Cham, Switzerland, 2021. [CrossRef]

2. Visvizi, A. Artificial Intelligence (AI): Explaining, Querying, Demystifying. In Artificial Intelligence and Its Contexts. Advanced Sciences and Technologies for Security Applications; Visvizi, A., Bodziany, M., Eds.; Springer: Cham, Switzerland, 2021. [CrossRef]

3. Sætra, H.S. A Typology of AI Applications in Politics. In Artificial Intelligence and Its Contexts. Advanced Sciences and Technologies for Security Applications; Visvizi, A., Bodziany, M., Eds.; Springer: Cham, Switzerland, 2021. [CrossRef]

4. Sætra, H.S.; Coeckelbergh, M.; Danaher, J. The AI ethicist's dilemma: Fighting Big Tech by supporting Big Tech. AI Ethics 2021. [CrossRef]

5. Bodziany, M. Ethical Conditions of the Use of Artificial Intelligence in the Modern Battlefield-Towards the "Modern Culture of Killing". In Artificial Intelligence and Its Contexts. Advanced Sciences and Technologies for Security Applications; Visvizi, A., Bodziany, M., Eds.; Springer: Cham, Switzerland, 2021. [CrossRef]

6. Loukis, E.N.; Maragoudakis, M.; Kyriakou, N. Artificial intelligence-based public sector data analytics for economic crisis policymaking. Transform. Gov. People Process Policy 2020, 14, 639-662. [CrossRef]

7. Chohan, S.R.; Hu, G.; Khan, A.U.; Pasha, A.T.; Sheikh, M.A. Design and behavior science in government-to-citizens cognitivecommunication: A study towards an inclusive framework. Transform. Gov. People Process Policy 2021, 15, 532-549. [CrossRef]

8. Floridi, L.; Cowls, J. A Unified Framework of Five Principles for AI in Society. In Ethics, Governance, and Policies in Artificial Intelligence. Philosophical Studies Series; Floridi, L., Ed.; Springer: Cham, Switzerland, 2021; Volume 144. [CrossRef]

9. Sætra, H.S. AI in Context and the Sustainable Development Goals: Factoring in the Unsustainability of the Sociotechnical System. Sustainability 2021, 13, 1738. [CrossRef]

10. Reis, J.; Santo, P.; Melão, N. Impact of Artificial Intelligence Research on Politics of the European Union Member States: The Case Study of Portugal. Sustainability 2020, 12, 6708. [CrossRef]

11. Alsharkawi, A.; Al-Fetyani, M.; Dawas, M.; Saadeh, H.; Alyaman, M. Poverty Classification Using Machine Learning: The Case of Jordan. Sustainability 2021, 13, 1412. [CrossRef] 
12. Espín-León, A.M.; Jimeno-Morenilla, A.; Pertegal-Felices, M.L.; Azorín-López, J. Cultural Identity Distance Computation through Artificial Intelligence as an Analysis Tool of the Amazon Indigenous People. A Case Study in the Waorani Community. Sustainability 2020, 12, 9513. [CrossRef]

13. Troisi, O.; Grimaldi, M.; Loia, F. Redesigning Business Models for Data-Driven Innovation: A Three-Layered Framework. In Research and Innovation Forum 2020. RIIFORUM 2020. Springer Proceedings in Complexity; Visvizi, A., Lytras, M.D., Aljohani, N.R., Eds.; Springer: Cham, Switzerland, 2021. [CrossRef]

14. Chen, Y.; Biswas, M.I. Turning Crisis into Opportunities: How a Firm Can Enrich Its Business Operations Using Artificial Intelligence and Big Data during COVID-19. Sustainability 2021, 13, 12656. [CrossRef]

15. Saeedi, K.; Almalki, M.D.; Aljeaid, D.; Visvizi, A.; Aslam, M.A. Design Pattern Elicitation Framework for Proof of Integrity in Blockchain Applications. Sustainability 2020, 12, 8404. [CrossRef]

16. Meppelink, J.; Van Langen, J.; Siebes, A.; Spruit, M. Beware Thy Bias: Scaling Mobile Phone Data to Measure Traffic Intensities. Sustainability 2020, 12, 3631. [CrossRef] 